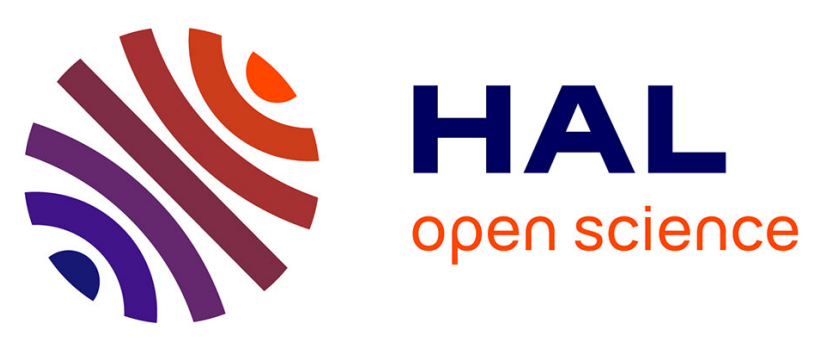

\title{
A Convenient Approach to Luminescent Cyclometalated Platinum(II) Complexes with Organometallic $\pi$-Bonded Benzenedithiolate
}

\author{
Hugo Sesolis, Geoffrey Gontard, Anny Jutand, Maria Pia Gullo, Elisa \\ Bandini, Andrea Barbieri, Hani Amouri
}

\section{To cite this version:}

Hugo Sesolis, Geoffrey Gontard, Anny Jutand, Maria Pia Gullo, Elisa Bandini, et al.. A Convenient Approach to Luminescent Cyclometalated Platinum(II) Complexes with Organometallic $\pi$ Bonded Benzenedithiolate. European Journal of Inorganic Chemistry, 2018, 2018 (34), pp.3804-3812. 10.1002/ejic.201800561 . hal-02386425

\section{HAL Id: hal-02386425 https://hal.science/hal-02386425}

Submitted on 29 Nov 2019

HAL is a multi-disciplinary open access archive for the deposit and dissemination of scientific research documents, whether they are published or not. The documents may come from teaching and research institutions in France or abroad, or from public or private research centers.
L'archive ouverte pluridisciplinaire HAL, est destinée au dépôt et à la diffusion de documents scientifiques de niveau recherche, publiés ou non, émanant des établissements d'enseignement et de recherche français ou étrangers, des laboratoires publics ou privés. 


\title{
Convenient Approach to Luminescent Cyclometalated Platinum(II) Complexes with Organometallic $\pi$-bonded
} Benzenedithiolate

\author{
Hugo Sesolis, ${ }^{\ddagger}$ Geoffrey Gontard, ${ }^{\ddagger}$ Anny Jutand, ${ }^{* \#}$ Maria Pia Gullo, ${ }^{\dagger}$ Elisa Bandini, ${ }^{\dagger}$ Andrea Barbieri, ${ }^{\dagger}$ \\ and Hani Amouri*
}

\begin{abstract}
A family of neutral cyclometalated platinum(II) complexes $\left[\left(C^{\wedge} N\right) P t\left(\eta-S^{\wedge} S\right)\right]$ with $\pi$-bonded benzenedithiolate $\left\{\left(\eta-S^{\wedge} S\right)=\right.$ $\left.\mathrm{Cp}{ }^{*} \mathrm{Ru}\left(\mathrm{C}_{6} \mathrm{H}_{4} \mathrm{~S}_{2}\right)\right\}$ and various cyclometalated ligands, $\left\{\left(\mathrm{C}^{\wedge} \mathrm{N}\right)=2-\right.$ phenylpyridine (ppy), (2); 2,4-difluorophenylpyridine (F2ppy) (3), benzo[h]quinoline (bzq) (4); dibenzo[f,h]quinoline (dbzq) (5) \} were prepared and fully characterized. For comparison purposes the related bipyridine platinum (II) complex [(bpy)Pt( $\left.\left.\eta-\mathrm{S}^{\wedge} \mathrm{S}\right)\right][\mathrm{OTf}](6)$ was also prepared. The electrochemistry behavior of these complexes was investigated and shows the enhanced stability of these compounds toward oxidation due to the presence of $\mathrm{Cp}{ }^{*} \mathrm{Ru}$ moiety which is now $\pi$-bonded to the benzenedithiolato group. Moreover several complexes were identified by single crystal X-ray molecular structures. To the best of our knowledge these are the first structures to be reported for cyclometalated platinum complexes with a $\pi$-bonded benzenedithiolate (bdt) ligand. All of the complexes are luminescent in fluid solution at room temperature and in glassy solution at $77 \mathrm{~K}$; their emission properties can be tuned through ligand variation.
\end{abstract}

\section{Introduction}

Square-planar bidentate cyclometalated platinum(II) complexes represent an important class of compounds due to their attractive photochemical and photophysical properties. ${ }^{[1-5]}$ Such compounds have shown successful applications as luminescent materials in organic light-emitting devices (OLEDs), ${ }^{[2-3,6]}$ molecular sensors, ${ }^{[7-8]}$ photochromic materials ${ }^{[9-10]}$ and as phosphorescent probes for bioimaging. ${ }^{[11]}$ Interests in such compounds are motivated in part due to the cyclometalation effect which improves luminescent efficiencies compared to their related diimine counterparts. ${ }^{[12-14]}$ The strong $\sigma$-donicity of the cyclometalated carbon center raises the energy of the non-emitting metal-centered ( $d$-d) states above the triplet energy of the cyclometalated ligand. ${ }^{[15-19]}$

To this end various cyclometalated platinum complexes were described with $\beta$-diketonate ligands, ${ }^{[20-21]}$ 8hydroxyquinolinate, ${ }^{[22-23]}$ carbenes $^{[24-27]}$, phosphinine coligand ${ }^{[27]}$ and more recently with a phosphinoferrocene ligand. ${ }^{[28]}$ However cyclometalated platinum(II) complexes containing

\footnotetext{
‡ Sorbonne Université-Faculté des Sciences et Ingénerie Campus Pierre et Marie Curie, CNRS, IPCM (UMR 8232), 4 place Jussieu, 75252 Paris cedex 05, France. E-mail: hani.amouri@sorbonne-universite.fr

${ }^{\dagger}$ Istituto per la Sintesi Organica e la Fotoreattività (ISOF), Consiglio Nazionale delle Ricerche (CNR), Via Gobetti 101, 40129 Bologna BO, Italy. E-mail: andrea.barbieri@isof.cnr.it

\# PASTEUR, Département de chimie, Ecole normale supérieure, PSL University, Sorbonne Université, CNRS, 24 rue Lhomond F-75231 Paris, France.E-mail: Anny.Jutand@ens.fr.

Supporting information for this article is given via a link at the end of the document: XRD, Photophysic and electrochemical spectra.
}

benzenedithiolate (bdt) as coligands are not very common, only two square planar anionic cyclometalated $\mathrm{Pt}(\mathrm{II})$ complexes $\left[\left(\mathrm{C}^{\wedge} \mathrm{N}\right) \mathrm{Pt}\left(\mathrm{S}^{\wedge} \mathrm{S}\right)\right]\left[\mathrm{NBu}_{4}\right]\left\{\left(\mathrm{C}^{\wedge} \mathrm{N}=\mathrm{ppy}=2\right.\right.$-phenylpyridine; tbpiq $=4$ $t$-butylphenyl)isoquinoline; $\left(\mathrm{S}^{\wedge} \mathrm{S}\right)=$ benzenedithiolate $\left.(\mathrm{bdt})\right\}$ were described. ${ }^{[29]}$ However it is mentioned that these compounds are stable in the solid state but slowly decompose in solution in the presence of air and ambient light perhaps due to their anionic character.

In this paper we describe a novel approach to prepare a variety of cyclometalated platinum complexes with $\pi$-bonded benzenedithiolate $\left\{\left(\eta-S^{\wedge} S\right)=C p^{*} R u\left(C_{6} H_{4} S_{2}\right)\right\}$. The presence of the organometallic $\eta-C p^{*} \mathrm{Ru}^{+1}$ unit at the dithiolato ligand brings stability to these neutral cyclometallated platinum compounds in solid state and in solution. A short communication on this work has been reported by some of us. ${ }^{[30]}$ In this present work we extend our synthetic approach to other cyclometallated platinum species and also to the related bipyridyl platinum compound. Their photophysical and electrochemical behavior have been investigated.

Our group has shown that organometallic moieties such as $\mathrm{Cp}^{*} \mathrm{M}\left(\mathrm{Cp}^{*}=\right.$ pentamethylcyclopentadienyl, $\mathrm{M}=\mathrm{Ru}, \mathrm{Rh}$ and $\left.\mathrm{Ir}\right)$ can stabilize reactive intermediates by modifying their electronic properties. ${ }^{[31-38]}$ More recently we have reported the synthesis of organometallic $\pi$-bonded quinones $\left[\mathrm{Cp}^{*} \mathrm{M}\left(\eta-\mathrm{C}_{6} \mathrm{H}_{4} \mathrm{O}_{2}\right)\right]^{\mathrm{n}}(\mathrm{M}=\mathrm{Ru}$, $\mathrm{n}=-1 ; \mathrm{M}=\mathrm{Rh}, \mathrm{Ir}, \mathrm{n}=0$ ) and their usage as organometallic ligands for the preparation of a unique type of supramolecular assemblies with useful luminescent properties. ${ }^{[39-41]}$ Since this metal-based-ligand approach proved to be very effective in the modulation of electronic properties of the Ru(polypyridyl), $\mathrm{Pt}$ (terpy) and $\mathrm{Pt}(\mathrm{bpy})$ chromophores, ${ }^{[42-45]}$ we sought to prepare the related $\pi$-bonded benzenedithiolate complex $\left[\mathrm{C} p^{*} \mathrm{Ru}(\eta-\right.$ $\left.\left.\mathrm{C}_{6} \mathrm{H}_{4} \mathrm{~S}_{2}\right)\right]^{-}$(1) and use it as a tuned sulfur-containing ligand towards square planar platinum chromophore, which, according to Pearson's HSAB concept, is considered as a soft metal ion preferring coordination by soft ligand such as 1 . The presence of the $\mathrm{Cp}^{*} \mathrm{Ru}$ moiety at the arene ring of the benezenedithiolate allows also a fine tuning of the electronic donating properties of the sulfur centers which stabilizes the HOMO levels. ${ }^{[30,46]}$ The electrochemical and photophysical properties were studied and showed that these compounds are luminescent at room temperature in fluid solution and in frozen solvent at $77 \mathrm{~K}$.

\section{Results and discussion}

\section{Synthesis}

The target platinum complexes 2-5 were prepared by treatment of the $\pi$-bonded benzenedithiolate $[\mathrm{Na}]\left[\mathrm{Cp}{ }^{*} \mathrm{Ru}(\eta-\right.$ $\left.\mathrm{C}_{6} \mathrm{H}_{4} \mathrm{~S}_{2}\right)$ ] (Na-1) with the appropriate solvated cyclometalated platinum compounds (Scheme 1). Reaction work-up allowed the isolation of these complexes in reasonable to good yields. The benzenedithiolate metal $\pi$-complex $(\mathrm{Na}-1)$ was prepared from 
the halogenated ruthenium complex $\left[\mathrm{Cp}{ }^{*} \mathrm{Ru}\left(\eta-\mathrm{C}_{6} \mathrm{H}_{4} \mathrm{Cl}_{2}\right][\mathrm{OTf}]\right.$ upon treatment with excess of $\mathrm{NaSH}$. All Compounds were fully characterized and in addition single crystal X-ray diffraction study was carried out on three of the above molecules (vide infra). For instance, the ${ }^{1} \mathrm{H}-\mathrm{NMR}$ spectrum of $\left[(\mathrm{ppy}) \mathrm{Pt}\left(\eta-\mathrm{S}^{\wedge} \mathrm{S}\right)\right]$ (2) recorded in $\mathrm{CD}_{2} \mathrm{Cl}_{2}$ showed the presence of six multiplets in a range of $7.0 \mathrm{ppm}$ and $9.5 \mathrm{ppm}$ corresponding to the two nonequivalent rings of the ppy ligand, two multiplets at $\delta 5.73$ ppm, and $\delta 5.05 \mathrm{ppm}$ which are attributed to the coordinated 1,2-benzenedithiolate, and a singlet at $\delta 1.76 \mathrm{ppm}$ for the $\eta$ $\mathrm{Cp}{ }^{*} \mathrm{Ru}$. These signals are downfield relative to the free $\pi$ bonded 1,2-benezenedithiolate complex $\left[\mathrm{Cp}{ }^{*} \mathrm{Ru}\left(\eta-\mathrm{C}_{6} \mathrm{H}_{4} \mathrm{~S}_{2}\right)\right]^{-}$(1). The other compounds displayed similar feature. Full experimental data for 1-5 are given in the experimental section.

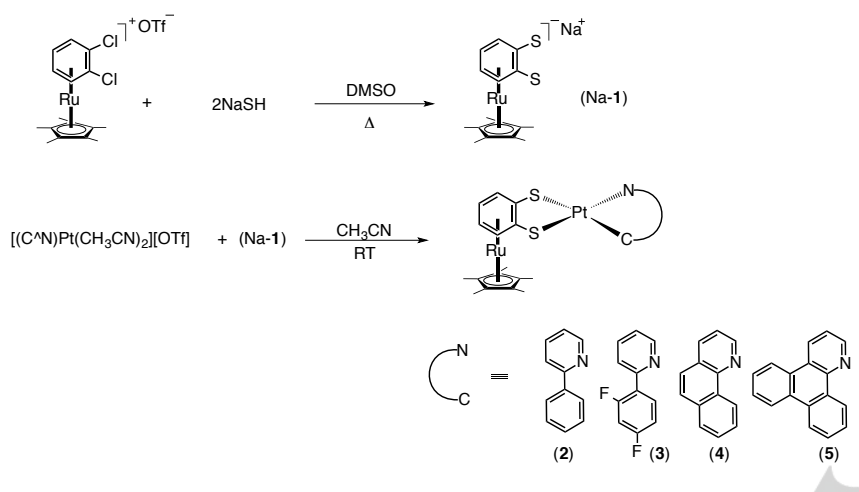

Scheme 1. Synthesis of cyclometalated platinum complexes 2-5.

On the other hand and for comparison purposes, we prepared the related complex [(bpy) Pt( $\left.\left.\eta-S^{\wedge} S\right)\right][O T f](6)$ displaying a bipyridine ligand instead of a phenylpyridine. This compound was prepared straightforward by treatment of the precursor complex [(bpy) $\left.\mathrm{Pt}\left(\mathrm{C}_{6} \mathrm{H}_{4} \mathrm{~S}_{2}\right)\right]\left(6^{\prime}\right)^{[47]}$ with the solvated ruthenium species $\left[\mathrm{Cp}{ }^{*} \mathrm{Ru}\left(\mathrm{CH}_{3} \mathrm{CN}\right)_{3}\right][\mathrm{OTf}]$ (Scheme 2). Complex 6 was fully characterized by spectroscopic technique and the identity of the compound was confirmed by single crystal $\mathrm{X}$-ray diffraction study (vide infra).

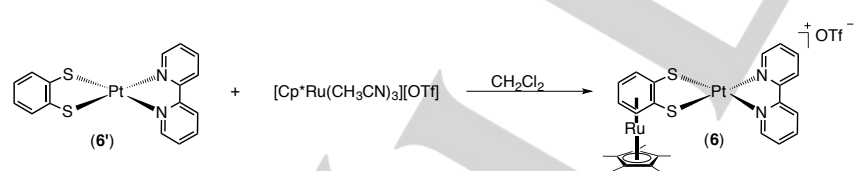

Scheme 2. Synthesis of the bipyridyl platinum complex 6 .

It is noteworthy that, this straightforward synthetic approach was not applicable to the preparation of the cyclometalated platinum complexes 2-5. Instead, when the precursor complex $\left[(\right.$ ppy $\left.) \mathrm{Pt}\left(\mathrm{C}_{6} \mathrm{H}_{4} \mathrm{~S}_{2}\right)\right]\left[\mathrm{NBu}_{4}\right] \quad\left(2^{\prime}\right)$ was treated with $\left[\mathrm{Cp}{ }^{*} \mathrm{Ru}\left(\mathrm{CH}_{3} \mathrm{CN}\right)_{3}\right][\mathrm{OTf}]$, only intractable materials were obtained, suggesting that $\pi$-complexation of the arene ring of the benzenedithiolate did not occur.

\section{X-ray molecular structures of 2-3, 5 and 6.}

Convenient crystals of compounds 2, $\mathbf{3}$ and $\mathbf{5}$ for X-ray study were obtained from $\mathrm{CH}_{2} \mathrm{Cl}_{2}$ /diethylether via slow diffusion technique, while for complex 6 crystals were obtained from acetone/diethylether mixture following similar procedure. Table S1 summarizes the experimental and structure refinement parameters for compounds 2, 3, 5 and $\mathbf{6}$, selected bond distances and lengths are given in Table 1.

The X-ray structure of [(ppy)Pt(1)] (2) (Figure 1a) revealed the presence of two independent molecules $a$ and $b$ in the unit cell unlike those of complexes $\mathbf{3}, \mathbf{5}$ and $\mathbf{6}$. All compounds show common feature such as the $S, S^{\prime}$ chelating mode of the $\pi$ bonded dithiolate to $\mathrm{Pt}(\mathrm{ppy})$ core in $\mathbf{2 , 3}$ and $\mathbf{5}$ and to $\mathrm{Pt}(\mathrm{bpy})$ in 6 via both sulfur atoms.

Table 1. Selected bond distances for 2-3 and 5-6.

\begin{tabular}{l|l|l|l|l}
\hline \hline Compounds & $\mathbf{2}$ & $\mathbf{3}$ & $\mathbf{5}$ & $\mathbf{6}$ \\
\hline \hline C1-S1 & $1.750(5)$ & $1.744(5)$ & $1.744(3)$ & $1.756(2)$ \\
C2-S2 & $1.745(5)$ & $1.738(5)$ & $1.746(3)$ & $1.747(3)$ \\
\hline Ru1-C1 & $2.290(5)$ & $2.286(4)$ & $2.297(3)$ & $2.266(2)$ \\
Ru1-C2 & $2.290(5)$ & $2.308(5)$ & $2.288(3)$ & $2.267(2)$ \\
Ru1-C3 & $2.214(5)$ & $2.204(5)$ & $2.205(4)$ & $2.214(2)$ \\
Ru1-C4 & $2.197(5)$ & $2.189(5)$ & $2.202(4)$ & $2.211(3)$ \\
Ru1-C5 & $2.202(5)$ & $2.203(5)$ & $2.199(4)$ & $2.199(4)$ \\
Ru1-C6 & $2.200(5)$ & $2.211(4)$ & $2.209(3)$ & $2.208(3)$ \\
Pt1-S1 & $2.295(5)$ & $2.313(4)$ & $2.275(3)$ & $2.261(1)$ \\
Pt1-S2 & $2.301(5)$ & $2.269(4)$ & $2.305(3)$ & $2.252(1)$ \\
Pt1-N1 & & & & $2.047(3)$ \\
Pt1-N2 & & & & $2.051(3)$ \\
\hline S1-Pt1-S2 & $89.14(5)$ & $89.25(5)$ & $89.72(4)$ & $89.93(2)$ \\
S2-Pt1-C7 & $95.82(13)$ & $94.38(14)$ & $95.19(8)$ & \\
C7-Pt1-N1 & $79.94(19)$ & $81.33(19)$ & $81.16(11)$ & \\
N1-Pt1-S1 & $95.05(15)$ & $95.04(14)$ & $93.94(8)$ & $95.62(7)$ \\
N2-Pt1-S2 & & & & $94.58(7)$ \\
N1-Pt1-N2 & & & & $79.86(9)$ \\
\hline \hline
\end{tabular}

To the best of our knowledge these are the first molecular structure of cyclometalated platinum complexes with a benzenedithiolate ligand. However, only three examples were reported: a square planar (ppy)Au(III)- dithiolate ${ }^{[48]}$, a (ppy) $\mathrm{Pt}(\mathrm{II})$ with a sulfur rich 1,2 dithiolato-tetrathiafulvene ligand ${ }^{[49]}$ and a heterometallic species featuring a cyclometallated $\mathrm{Pt}(\mathrm{II})$-dithiolate and $\mathrm{PCy}_{3}-\mathrm{Au}(\mathrm{I})$ with $\mathrm{Pt}---\mathrm{Au}$ metallophilic interaction. ${ }^{[29]}$ In complexes 2, 3 and 5, the $\mathrm{Pt}$ (II) center is also coordinated to one cyclometalated carbon and to a nitrogen atom which describes a distorted square planar coordination geometry around the metal center, with N1-Pt-C7 angle of $80.16(21)^{\circ}$ and S1-Pt-S2 angle of $89.33(19)^{\circ}$ for 2 , of $81.33(19)^{\circ}$ and $89.25(5)^{\circ}$ for 3 and of $81.16(19)^{\circ}$ and $89.72(5)^{\circ}$ for 5 . The platinum center and the four-ligand atoms $\mathrm{S} 1 \mathrm{~S} 2 \mathrm{~N} 1 \mathrm{C} 7$ are essentially coplanar with negligible deviation from the plane: 0.048(10) $\AA$ for $2,0.019(5) \AA$ for $3,0.040(3) \AA$ for 5 and $0.015(3) \AA$ for 6.

The structure also shows that the benzenedithiolate unit is coordinated to the $\mathrm{Cp}^{*} \mathrm{Ru}$ moiety via the carbons in $\eta^{6}$ fashion. Further in complexes 2, 3, 5 and 6, the C1-S1 and C2-S2 bond distances are on average of 1.74 to 1.75 $\AA$ slightly shorter than those reported for [(ppy)Au(tdt)] (1.759(7) and 1.769(9) $\AA$ ) tdt = 3,4-toluenedithiolate. In the cyclometalated platinum complexes, the nitrogen and 
carbon atoms cannot be distinguished crystallographically. Both atoms randomly occupy the same site through the crystal lattice and thus the bond distances values of $\mathrm{Pt}-\mathrm{C}$, $\mathrm{Pt}-\mathrm{N}$ and $\mathrm{Pt}-\mathrm{S}$ are averaged.

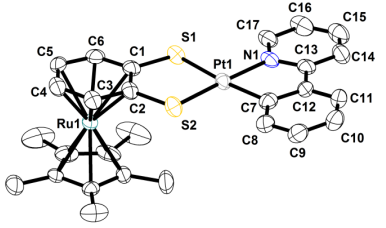

2

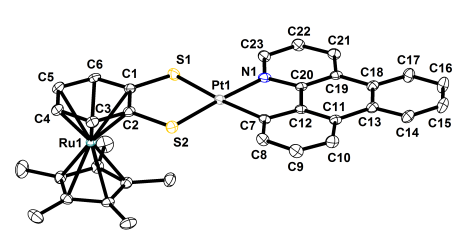

5

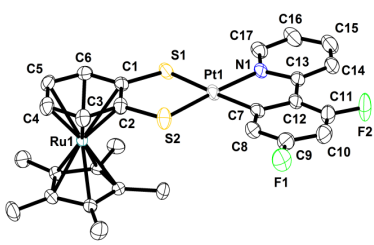

3

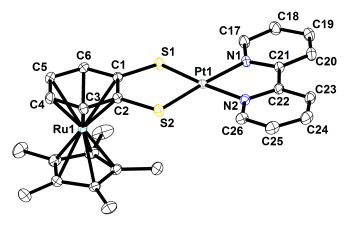

6
Figure 1a. Molecular structures of complexes 2, 3, $\mathbf{5}$ and $\mathbf{6}$ with hydrogen atoms omitted for clarity at $30 \%$ probability

Examination of the packing of all complexes showed no Pt--Pt interactions among individual units, however $\pi-\pi$ interactions among dimers were observed mainly between the sulfur and the bipyridine units $(\mathrm{d}=3.57 \AA),(\mathrm{d}=3.26 \AA)$ while for the cyclometalated 2, 3 and $\mathbf{5}$ a series $\pi-\pi$ interactions $(d=3.65 \AA$ ), $(d=3.48 \AA)$ and $(d=3.60 \AA)$ occurred between the $C p^{*} R u$ unit and the cyclometalated ligands (Figure $1 \mathrm{~b}$ ).

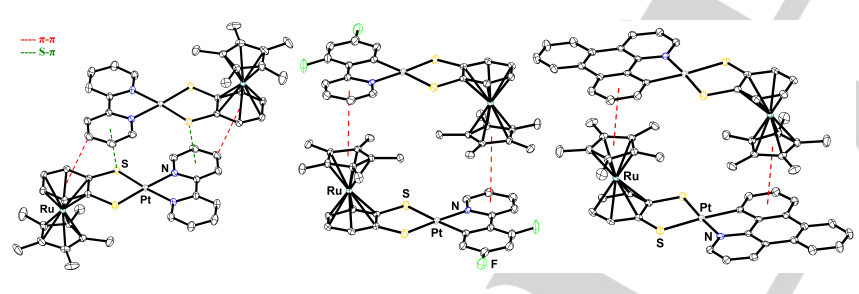

Figure 1b. Dimer formation through $\pi-\pi$ interactions between individual molecules in 6, 3, and $\mathbf{5}$.

It is noteworthy to mention that all of the complexes were stable in solution for a long period of time and did not show signs of decomposition. In the solid state these compounds could be kept for months under argon atmosphere.

\section{Electrochemistry.}

The cyclic voltammetry (CV) of complexes 3-6 (See Figures S2-S5) was investigated to characterize their HOMO and LUMO levels and the electronic influence of the ligands on the HOMO/LUMO gap. The cyclic voltammetry was performed in dry and degassed solvents containing ${ }^{n} \mathrm{Bu}_{4} \mathrm{NBF}_{4}$ (0.3M) as supporting electrolyte at a vitreous Carbon disk electrode $(d=1$ $\mathrm{mm}$ ) at the scan rate of 0.5 or $1 \mathrm{Vs}^{-1}$. The reference was a Saturated Calomel Electrode (SCE, separated from the solution via a bridge containing the solvent and supporting electrolyte), the counter-electrode was a Platinum wire. All experiments were performed under Argon atmosphere at room temperature (ca. $20{ }^{\circ} \mathrm{C}$ ). The solvent was selected regarding to complexes solubility (Table 2). Very low oxidation and reduction peak currents were observed for complexes 3,4 due to severe lack of solubility. Nevertheless, the oxidation and reduction peak potentials could be determined. Complex 2 was not enough soluble to allow any $\mathrm{CV}$ characterization. For comparison, the $\mathrm{CV}$ of the non-metallated complexes $\left[(\mathrm{ppy}) \mathrm{Pt}\left(\mathrm{C}_{6} \mathrm{H}_{4} \mathrm{~S}_{2}\right)\right]\left[\mathrm{NBu}_{4}\right]$ $\left(2^{\prime}\right)^{[29]}$ (Figure $\mathrm{S} 6$ ) and $\left[\left(\right.\right.$ bpy) Pt $\left.\left(\mathrm{C}_{6} \mathrm{H}_{4} \mathrm{~S}_{2}\right)\right]\left(6^{\prime}\right)^{[47]}$ (Figure $\mathrm{S} 7$ ) that are not reported in literature was also investigated. The reduction and oxidations potentials of complexes 3-6, 2' and 6' are gathered in Table 2 .

The CV of relevant non-metallated complexes with $\mathrm{O}^{\wedge} \mathrm{O}$ ligands instead of $S^{\wedge} S$ ligands is reported. Whereas reduction peaks were well defined, the oxidation peaks were "ill defined" as it is typically found for cyclometallated $\mathrm{Pt}(\mathrm{II})$ complexes. ${ }^{[13,21]}$

Complexes 3-6 exhibited at least two successive irreversible oxidation peaks (see Figures S2-S5); a third one was observed for complexes 3 and 6 (Table 2). All oxidation peaks were irreversible at the time scale of the CV (scan rate up to $2 \mathrm{Vs}^{-1}$ ). The lowest oxidation potential which characterizes the HOMO, is mainly located on the $\mathrm{S}$ group of the bdt ligand which is oxidized first. The second oxidation peak was assigned to the oxidation of the $\mathrm{Pt}$ (II) center of the oxidized complexes to $\mathrm{Pt}(\mathrm{III})$, the third one when present was assigned to the oxidation of $\mathrm{Ru}(\mathrm{II})$ center of the bis-oxidized complex. Complexes 3-5 exhibited one reversible or quasi-reversible reduction peak (see Figure S2-S4 and Table 2, entries 2-4). The LUMO is thus located on their $\mathrm{N}^{\wedge} \mathrm{C}$ ligands. The $\mathrm{CV}$ of $\mathbf{6}^{\prime}$ and $\mathbf{6}$ (Figures S5 and S7) exhibited two successive reversible reduction peaks in agreement with the ability of the ligated $\mathrm{N}^{\wedge} \mathrm{N}$ bpy to accept two successive electrons (Table 2, entries 5,6). The LUMO of complexes $\mathbf{6}$ and $\mathbf{6}$ ' is thus located on the bpy ligand.

The $\pi$-complexation by the $\mathrm{Cp}{ }^{*} \mathrm{Ru}$ unit in complexes $3-5$, makes the bdt ligand less easily oxidized when compare to the complex 2' (compare entries 2-4 with entry 1 in Table 2). The $\pi$ complexation by the $\mathrm{Cp}{ }^{\star} \mathrm{Ru}$ unit makes the complexes 3-5 more stable than 2' with respect to degradation by oxidation, which is observed (vide supra). Indeed in a previous work we investigated the electrochemistry properties of $\left[\mathrm{Cp}{ }^{*} \mid r-0-\left(\mathrm{C}_{6} \mathrm{H}_{4} \mathrm{~S}_{2-}\right.\right.$ $\left.\left.\kappa^{2}-S, S\right)\right]$ and the related dinuclear complex $\left[\mathrm{Cp}^{*} \operatorname{Ir}(\eta-\right.$ $\left.\left.\mathrm{C}_{6} \mathrm{H}_{4} \mathrm{~S}_{2}\right) \mid r \mathrm{rCp}^{*}\right][\mathrm{OTf}]_{2}$ containing a $\pi$-bonded bdt unit. The results demonstrated that the binuclear system becomes more stable and the bdt ligand is less easily oxidized when compared to the mononuclear iridium species $\left[\mathrm{Cp}^{*} \mid \mathrm{r}-\mathrm{O}-\left(\mathrm{C}_{6} \mathrm{H}_{4} \mathrm{~S}_{2}-\kappa^{2}-\mathrm{S}, \mathrm{S}\right)\right]{ }^{[50]} \mathrm{We}$ also notice that higher the conjugation in the $C^{\wedge} N$ ligand in complexes 3-5, the easier their reduction is (Table 2, entries 2-4).

The energetic gap $\Delta E(\mathrm{HOMO}-\mathrm{LUMO})$ (corresponding to the electronic transition of lower energy) can be estimated by determining the potential gap between the first oxidation potential and the first reduction potential: $\left|E_{\text {red }}^{0}-E_{\text {ox }}^{p}\right|$. The values of $E_{\text {ox }}^{p}$ were used instead of $E_{\text {ox }}^{0}$ because the latter could not be determined due to the irreversibility of the first oxidation of complexes 3-5. On one hand, one observes that the complexes are more and more easily reduced when the delocalisation of the $\mathrm{C}^{\wedge} \mathrm{N}$ ligand increases. On the other hand the $\pi$-complexation of the $\mathrm{Cp}^{*} \mathrm{Ru}$ unit stabilizes the HOMO versus the non-metallated complex and makes the complexes less easily oxidized. 
The complexes $\mathbf{6}$ and $\mathbf{6}^{\prime}$ containing one bpy ligand behaved differently. Indeed, the $\pi$-complexation by the $\mathrm{Cp}^{*} \mathrm{Ru}$ unit in complex 6 makes this complex more easily oxidized (Table 2, entries 5,6). Complex 6 is more easily reduced than complex $\mathbf{6}^{\prime}$. This might be related to the cationic character of $\mathbf{6}$. As expected, complexes $\mathbf{6}$ and $\mathbf{6}^{\prime}$ ligated to the bpy ligand $\left(N^{\wedge} N\right)$ are more easily reduced than complexes $\mathbf{2}^{\prime}$ and 3-5 ligated to $\left(\mathrm{C}^{\wedge} \mathrm{N}\right)$ cyclometallated ligands. This is due to the ability of the bpy ligand to more easily accept electrons than the investigated $\left(C^{\wedge} N\right)$ ligands. Consequently, the lower energy of LUMO orbitals in complex 6 when compared to 3-5 provides lower energetic gap $\Delta E$ (HOMO-LUMO) for the bipyridne $\mathrm{Pt}$ complex compared to the cyclometallated ones, in agreement with the photophysical properties (vide infra).

Table 2. Redox Properties of Complexes

\begin{tabular}{|c|c|c|c|c|}
\hline Entry & Complex & Solvent & $\begin{array}{l}\text { Oxidation } \\
\text { potential } \\
\text { V vs SCE }\end{array}$ & $\begin{array}{l}\text { Reduction } \\
\text { potential } \\
\text { V vs SCE }\end{array}$ \\
\hline 1 & $\begin{array}{l}{\left[(\mathrm{ppy}) \mathrm{Pt}\left(\mathrm{C}_{6} \mathrm{H}_{4}\right.\right.} \\
\left.\left.\mathrm{S}_{2}\right)\right]\left[\mathrm{NBu}_{4}\right]\left(\mathbf{2}^{\prime}\right)\end{array}$ & $\mathrm{CH}_{3} \mathrm{CN}$ & $\begin{array}{c}E_{\text {Ox }}^{p}=+0.26 \\
(\text { irrev. })^{a} \\
E_{\text {Ox }}^{p}=+0.72 \\
(\text { irrev. })^{a}\end{array}$ & $\begin{array}{c}E_{\text {Red }}^{p}=-2.24 \\
\text { (quasi rev., } \Delta E= \\
106 \mathrm{mV} \text { ) }\end{array}$ \\
\hline 2 & $\begin{array}{c}{[(F 2 p p y) P t(\eta-} \\
\left.\left.S^{\wedge} S\right)\right](3)\end{array}$ & $\mathrm{CH}_{3} \mathrm{CN}$ & $\begin{array}{c}E_{\text {Ox }}^{p}=+0.63 \\
\quad(\text { irrev. })^{a} \\
E_{\text {Ox }}^{p}=+0.97 \\
\quad(\text { irrev. })^{a} \\
E_{\text {Ox }}^{p}=+1.33 \\
\text { (irrev. })^{a}\end{array}$ & $\begin{array}{c}E_{\text {Red }}^{0}=-1.97 \\
(\text { rev.) } \\
E_{\text {Red }}^{p}=-2.61 \\
\text { (quasi rev. , } \Delta E \\
=360 \mathrm{mV} \text { ) }\end{array}$ \\
\hline 3 & $\begin{array}{l}{[(\mathrm{bzq}) \mathrm{Pt}(\eta-} \\
\left.\left.\mathrm{S}^{\wedge} \mathrm{S}\right)\right](\mathbf{4})\end{array}$ & $\mathrm{CH}_{3} \mathrm{CN}$ & $\begin{array}{c}E_{\text {Ox }}^{p}=+0.81 \\
(\text { irrev. })^{\mathrm{a}} \\
E_{\text {Ox }}^{p}=+1.13 \\
(\text { irrev. })^{\mathrm{a}}\end{array}$ & $\begin{array}{c}E_{\text {Red }}^{p}=-1.91 \\
\text { (quasi rev., } \Delta E= \\
121 \mathrm{mV})^{\mathrm{a}}\end{array}$ \\
\hline 4 & $\begin{array}{c}{[(\mathrm{dbzq}) \mathrm{Pt}(\eta-} \\
\left.\left.\mathrm{S}^{\wedge} \mathrm{S}\right)\right](5)\end{array}$ & DMF & $\begin{array}{c}E_{\text {Ox }}^{p}=+0.59 \\
(\text { irrev. })^{a} \\
E_{\text {Ox }}^{p}=+1.05 \\
(\text { irrev. })^{a}\end{array}$ & $\begin{array}{c}E_{\text {Red }}^{p}=-1.84 \\
\text { (quasi rev. } \Delta E= \\
92 \mathrm{mV} \text { ) }\end{array}$ \\
\hline 5 & $\begin{array}{c}{\left[(\mathrm{bpy}) \mathrm{Pt}\left(\mathrm{C}_{6} \mathrm{H}_{4}\right.\right.} \\
\left.\left.\mathrm{S}_{2}\right)\right]\left(6^{\prime}\right)\end{array}$ & $\mathrm{CH}_{3} \mathrm{CN}$ & $\begin{array}{c}E_{\text {Ox }}^{p}=+0.45 \\
\text { (quasi rev., } \\
\Delta E=135 \\
\mathrm{mV})^{\mathrm{a}} \\
E_{\text {ox }}^{p}=+0.93 \\
\text { (quasi rev., } \\
\Delta E=300 \\
\mathrm{mV})^{\mathrm{a}}\end{array}$ & $\begin{array}{c}E_{\text {Red }}^{0}=-1.30 \\
(\text { rev. })^{a} \\
E_{\text {Red }}^{0}=-1.95 \\
(\text { rev. })^{a}\end{array}$ \\
\hline 6 & $\begin{array}{c}{[(\mathrm{bpy}) \mathrm{Pt}(\eta-} \\
\left.\left.\mathrm{S}^{\wedge} \mathrm{S}\right)\right][\mathrm{OTf}](6)\end{array}$ & $\mathrm{CH}_{3} \mathrm{CN}$ & $\begin{array}{c}E_{\text {Ox }}^{p}=+0.35 \\
\text { (irrev. }^{\mathrm{b}} \\
E_{\text {ox }}^{p}=+1.03 \\
\text { (irrev. }^{\mathrm{b}} \\
E_{\text {Ox }}^{p}=+1.31 \\
\text { (irrev.) }^{\mathrm{b}}\end{array}$ & $\begin{array}{c}E_{\text {Red }}^{0}=-1.19 \\
(\text { rev. })^{b} \\
E_{\text {Red }}^{0}=-1.81 \\
(\text { rev. })^{b}\end{array}$ \\
\hline
\end{tabular}

All potentials were determined at a vitreous Carbon disk electrode ( $d$ $=1 \mathrm{~mm}$ ) at r.t. Solution of complexes 2', 3-6, and $\mathbf{6}^{\prime}$ (concentration less than $2 \mathrm{mM}$ due to insolubility problem) in solvent containing ${ }^{n} \mathrm{Bu}_{4} \mathrm{NBF}_{4}(0.3 \mathrm{M})$ as the supporting electrolyte. $E^{p}$ ox : oxidation peak potential. $E_{\text {Red }}^{p}$ : reduction peak potentials. $E_{\text {Red }}^{0}$ : standard potential. irrev.: irreversible. rev.: reversible. quasi rev. : quasi-reversible. ${ }^{a}$ At the scan rate of $0.5 \mathrm{Vs}^{-1} ;{ }^{\mathrm{b}}$ At the scan rate of $1 \mathrm{Vs}^{-1}$.

\section{Photophysical properties.}

Absorption. The UV-Vis absorption spectra for the complexes 2-6 have been measured in $\mathrm{CH}_{2} \mathrm{Cl}_{2}$ solution at room temperature. The molar extinction coefficients as function of wavelength are reported in Figure 2 and key parameters are summarized in Table 3.

Complexes 2 and 3 basically show the same absorption pattern, which doesn't seem to be perturbed by the change in the cyclometalating ligand from ppy (2) to F2ppy (3). On the other hand, the extended conjugation brought about by the introduction of the bzq and dbzq cyclometalating ligands in $\mathbf{4}$ and 5, respectively, induces a sizeable variation in their absorption spectra (Figure 2). A common feature to all complexes 2-5 is an envelop of intense transitions in the near UV region of the spectrum, between 250 and $350 \mathrm{~nm}$, with value of extinction coefficient at about $260 \mathrm{~nm}$ in the range 20.000$25.000 \mathrm{M}^{-1} \mathrm{~cm}^{-1}$. These can be assigned, by comparison with literature data, to intra-ligand (IL) $\pi, \pi^{*}$ transitions, being the energy very close to that reported for uncoordinated phenylpyridine. ${ }^{[51]}$ In all cases the lowest energy band in the visible region, displaying a moderate extinction coefficient, can be attributed to a mixed metal/ligand-to-ligand charge transfer (MLLCT) process. ${ }^{[46,52]}$ It should be noted that the coordination of the $\mathrm{Ru}\left(\mathrm{Cp}^{*}\right)$ fragment to the benzendithiolate (bdt) unit induces a blue shift of the lowest energy absorption band $\left(\lambda_{\max }=\right.$ 426 and $477 \mathrm{~nm}$ for 2 and 6 , respectively) with respect to that of

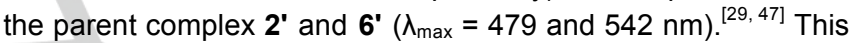
behavior can be explained by taking into account the stabilization of the molecular orbitals centered on the $\mathrm{Pt}(\mathrm{bdt})$ fragment, induced by the coordination of Ru(II), which does not influence the energy levels localized on the ppy ligand, but anyway increases the HOMO-LUMO gap and thus the amount of energy required for the charge transfer transition towards ppy ligand. ${ }^{[46]}$

Table 3. Absorption parameters $\lambda_{\max }, \mathrm{nm}\left(\varepsilon_{\max }, \mathrm{M}^{-1} \mathrm{~cm}^{-1}\right)^{a}$

$2259(21,800), 291(19,300), 426(9,000)$

$2^{\prime b}$ 280 (31,600), $336(5,700), 479(5,500)$

3 254 (17,700), $286(17,900), 420(8,200)$

4 264 (25,400), $358(9,200), 433(6,100)$

5 259 (30,100); 310 (11,600); $332(13,900) ; 380$ $(2,800)$

6 301 (27,100); 477 (3,400)

$6^{\prime c}$ 260 (34,500), $310(27,400), 542(6,960)$

${ }^{a}$ In $\mathrm{CH}_{2} \mathrm{Cl}_{2}$ solution at room temperature. ${ }^{b}$ Data from ref ${ }^{[29]} .{ }^{c}$ In $\mathrm{CH}_{3} \mathrm{CN}$, data from ref ${ }^{[47]}$. 


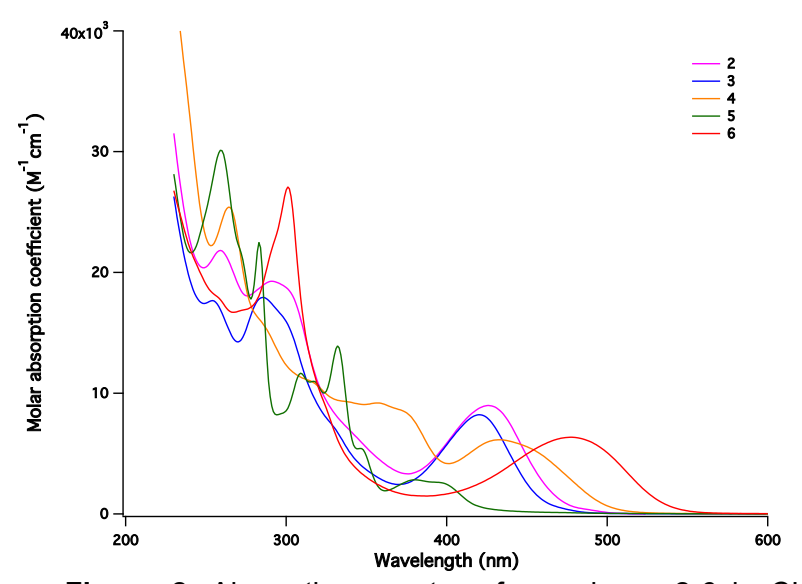

Figure 2. Absorption spectra of complexes 2-6 in $\mathrm{CH}_{2} \mathrm{Cl}_{2}$ solution at room temperature.

Emission. The photoluminescence spectra of 2-6 recorded in $\mathrm{CH}_{2} \mathrm{Cl}_{2}$ solution at room temperature and in $\mathrm{CH}_{2} \mathrm{Cl}_{2}: \mathrm{CH}_{3} \mathrm{OH}$ (1: 1) glassy mixture at $77 \mathrm{~K}$ have been collected in Figures 4 and 5 , respectively; the main photophysical parameters are summarized in Table 4. All complexes are luminescent in condensed media at low temperature (Figure 4) and display a faint but clearly detectable luminescence in de-aerated $\mathrm{CH}_{2} \mathrm{Cl}_{2}$ solution at room temperature (Figure 3 ), with the notable exception of 4 , for which a quantum yield of ca. $0.2 \%$ has been measured (Table 4). The hypsochromic shift of the emission on going from fluid to frozen solution and the almost featureless broad spectrum at rt confirm the CT nature of the excited states. Besides, the well-defined vibrational progression observed in the emission spectra of 2, 4 and 5 recorded at $77 \mathrm{~K}$, accounts for a mixed ${ }^{3} \mathrm{LC} / \mathrm{MLCT}$ nature for the emissive excited states of the complexes. Such assumption is also confirmed by emission lifetime values, standing in the microsecond time range similarly to other reported cyclometalated platinum(II) complexes. ${ }^{[1,4]}$ It is important to point out that the changing of the cyclometalating ligands along the series allows for a significant tuning of the luminescence color over a wide gamut range from blue to greenorange. Notably, the non-radiative rate constant of complexes 25 bearing the organometallic $\mathrm{Ru}\left(\mathrm{Cp}^{*}\right)$ ligand, calculated as $\mathrm{k}_{\mathrm{nr}}=$ $(1-\phi) / \tau$, decreases as the energy of the emitting state, taken as the highest energy emission maximum of the luminescence spectra recorded in solution at it (Table 4), decreases (Figure S8). This behavior apparently seems to contradict the "energy gap law" that predicts an enhancement of the non-radiative processes as the energy of the emitting state approaches that of the ground state (GS) ${ }^{[53-54]}$ For the Ru-polypyridine complexes, it is well known that the deactivation of the luminescent ${ }^{3} \mathrm{MLCT}$ levels to GS takes place via direct and mediated paths. ${ }^{[55]}$ The former is governed by the "energy gap law", while the latter operates via thermal population of levels lying higher in energy than the emitting ${ }^{3} \mathrm{MLCT}$ state. When these higher-lying levels are ${ }^{3} \mathrm{MC}$ in nature, enhanced non-radiative deactivation occurs owing to the strong MC-GS coupling. Thus, in our case, the latter mechanism seems to dominate the photophysical behavior.
Table 4. Emission parameters

\begin{tabular}{|c|c|c|c|c|c|}
\hline \multicolumn{3}{|c|}{$\mathrm{rt}^{a}$} & \multicolumn{3}{|c|}{$77 \mathrm{~K}^{b}$} \\
\hline & $\begin{array}{c}\lambda_{\max } \\
(\mathrm{nm})\end{array}$ & $\phi$ & $\tau(\mathrm{ns})$ & $\begin{array}{l}\lambda_{\max } \\
(\mathrm{nm})\end{array}$ & $\tau(\mu s)$ \\
\hline 2 & 518 & $1.0 \times 10^{-4}$ & 4.7 & 485 & 6.0 \\
\hline $2^{1 b}$ & 607 & - & $1.39 \times 10^{3}$ & 554 & 19.8 \\
\hline 3 & 525 & $0.5 \times 10^{-4}$ & 5.3 & 498 & 6.3 \\
\hline 4 & 590 & $19.7 \times 10^{-4}$ & 157.0 & 533 & 59.0 \\
\hline 5 & 496 & $0.7 \times 10^{-4}$ & 1.6 & 510 & 11.3 \\
\hline 6 & 605 & $1.0 \times 10^{-4}$ & 4.7 & 558 & 24.0 \\
\hline $6^{\prime c}$ & 703 & - & 460 & . & - \\
\hline
\end{tabular}

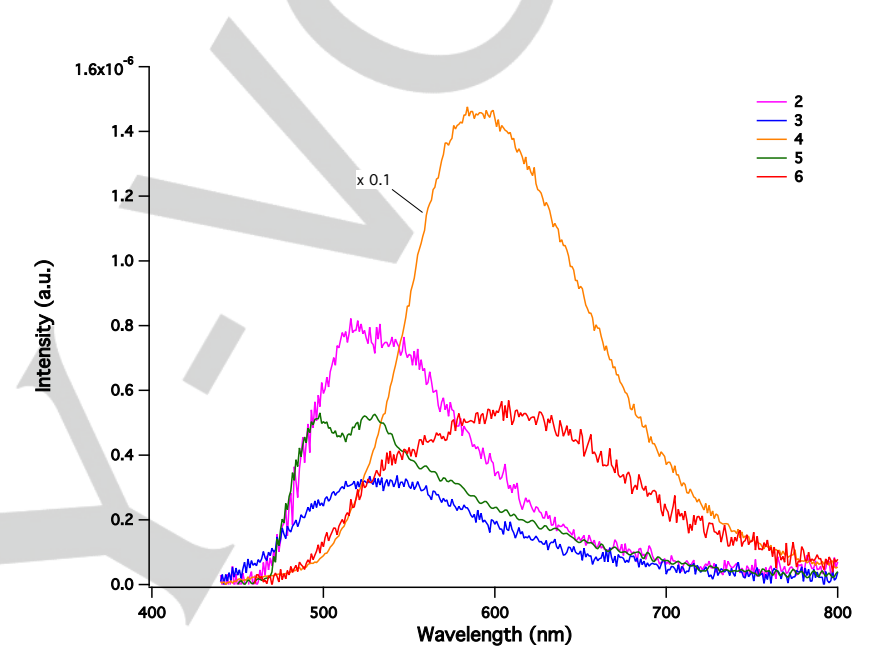

Figure 3. Emission spectra of 2-6 in $\mathrm{CH}_{2} \mathrm{Cl}_{2}$ solution at rt. The spectra have been rescaled for the relevant quantum yield.

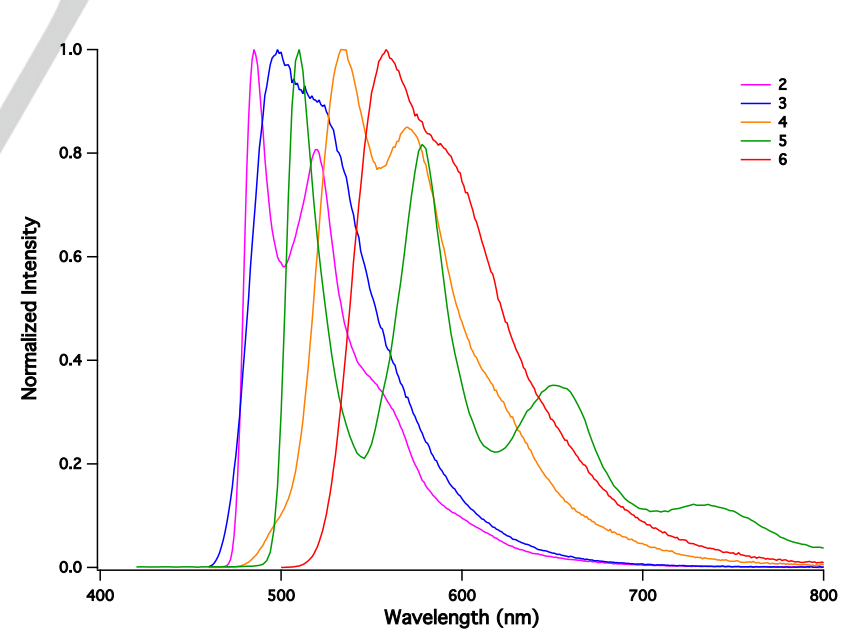

Figure 4. Normalized emission spectra of 2-6 in $\mathrm{CH}_{2} \mathrm{Cl}_{2}$ : $\mathrm{CH}_{3} \mathrm{OH}(1: 1)$ mixture at $77 \mathrm{~K}$.

\section{Concluding Remarks}

In this work we have reported a series of novel cyclometalated platinum complexes $\left[\left(C^{\wedge} N\right) \operatorname{Pt}\left(\eta-S^{\wedge} S\right)\right]$ with $\pi-$ bonded benzenedithiolate $\left\{\left(\eta-\mathrm{S}^{\wedge} \mathrm{S}\right)=\mathrm{Cp} p^{*} \mathrm{Ru}\left(\mathrm{C}_{6} \mathrm{H}_{4} \mathrm{~S}_{2}\right)\right\}$ and $\left\{\left(C^{\wedge} N\right)=\right.$ ppy, (2); F2ppy (3), bzq (4); dbzq (5). The related bipyridine platinum (II) compound is also described [(bpy)Pt( $\eta$ - 
$\left.\left.S^{\wedge} S\right)\right][O T f](6)$. Several complexes were identified by single crystal X-ray molecular structures. All of the complexes are luminescent in fluid solution at room temperature and in frozen solvent at $77 \mathrm{~K}$ and their emission properties can be tuned through ligand variation. Moreover complex [(bzq)Pt $\left.\left(\eta-S^{\wedge} S\right)\right](4)$ was found to be the most emissive among the series. The presence of the $\mathrm{Cp}^{*} \mathrm{Ru}$ at the bdt unit induces a blue shift in the absorption and emission properties of these complexes when compared to related compounds but without the $C p^{*} R u$ moiety. The electrochemistry studies revealed an enhanced stability of these compounds toward oxidation due to the $\pi$-bonding interaction between the benzenedithiolate and the $\eta-C p^{*} \mathrm{Ru}$ moiety. Moreover the cyclometalated compounds were found to reduce at more negative potentials when compared to the bpy series.

\section{Experimental Section}

\section{General experimental methods}

${ }^{1} \mathrm{H}$ NMR spectra were recorded at $300 \mathrm{MHz}$ in $\mathrm{CD}_{2} \mathrm{Cl}_{2}$ and data are reported as follows: chemical shift in ppm from tetramethylsilane with the solvent as an internal indicator $\left(\mathrm{CD}_{2} \mathrm{Cl}_{2} \delta 5.33 \mathrm{ppm}\right)$, multiplicity $(\mathrm{s}=$ singlet, $\mathrm{d}=$ doublet, $\mathrm{t}=$ triplet, $\mathrm{q}=$ quartet, $\mathrm{m}=$ multiplet or overlap of non-equivalent resonances), and integration. ${ }^{13} \mathrm{C}\left\{{ }^{1} \mathrm{H}\right\}$-NMR spectra were recorded at $75.4 \mathrm{MHz}$ in $\mathrm{CD}_{2} \mathrm{Cl}_{2}$ and data are reported as follows: chemical shift in ppm from tetramethylsilane with the solvent as an internal indicator $\left(\mathrm{CD}_{2} \mathrm{Cl}_{2} \delta 53.84 \mathrm{ppm}\right)$. Glassware was oven-dried prior to use. All reactions were carried out under an argon atmosphere. THF and diethyl ether were distilled from sodium-benzophenone. $\mathrm{CH}_{2} \mathrm{Cl}_{2}$ was distilled from $\mathrm{CaH}_{2}$. Other reagents were obtained from commercial suppliers and used as received. Infra-red spectra were measured using Tensor 27 (ATR diamond) Bruker spectrometer. IR data are reported as characteristic bands $\left(\mathrm{cm}^{-1}\right)$. Complexes [(ppy) Pt $\left.\left(\mathrm{C}_{6} \mathrm{H}_{4} \mathrm{~S}_{2}\right)\right]\left[\mathrm{NBu}_{4}\right]$ $\left(2^{\prime}\right)^{[29]}$ and $\left[(\mathrm{bpy}) \mathrm{Pt}\left(\mathrm{C}_{6} \mathrm{H}_{4} \mathrm{~S}_{2}\right)\right]\left(6^{\prime}\right)^{[47]}$ were prepared according to published procedures.

\section{Synthesis of [Na][Cp* Ru( $\left.\left(\eta-\mathrm{C}_{6} \mathrm{H}_{4} \mathrm{~S}_{2}\right)\right](\mathrm{Na}-1)$.}

A Schlenk flask under argon was charged with sodium hydrosulfide $(293 \mathrm{mg}, \quad 5.22 \mathrm{mmol}), \quad\left[\mathrm{Cp}{ }^{*} \mathrm{Ru}(\eta-1,2-\right.$ dichlorobenzene)][OTf] (95 mg, $0.18 \mathrm{mmol}$ ) and $1.5 \mathrm{~mL}$ of DMSO- $d_{6}$. This reaction mixture turned immediately to bluegreen and was heated at $175^{\circ} \mathrm{C}$ for $1 \mathrm{~h}$, during which the color turned to brown. An aliquot of the reaction mixture was removed by syringe and dissolved in DMSO- $d_{6}$ for ${ }^{1} \mathrm{H}$ NMR measurement. ${ }^{1} \mathrm{H}$ NMR indicated complete conversion of $\left[\mathrm{Cp}{ }^{*} \mathrm{Ru}(\eta-1,2-\right.$ dichlorobenzene)][OTf] to [Na][Cp* Ru(n- $\left.\left.\mathrm{C}_{6} \mathrm{H}_{4} \mathrm{~S}_{2}\right)\right]$. The solvent was removed under reduced pressure, and the residue was extracted with $\mathrm{CH}_{3} \mathrm{CN}(40 \mathrm{~mL}$ ) and filtered through a plug of Celite. Partial evaporation of the filtrate $(4 \mathrm{~mL})$ led to a brown solution of Na-1. ${ }^{1} \mathrm{H}$ NMR $\left(400 \mathrm{MHz}, \mathrm{DMSO}-d_{6}\right)$ : $\delta 5.43(\mathrm{~m}, 2 \mathrm{H}$, diene), $4.90\left(\mathrm{~m}, 2 \mathrm{H}\right.$, diene), $1.62\left(\mathrm{~s}, 15 \mathrm{H}, \mathrm{Cp}^{*}\right)$. This compound was air- and moisture-sensitive and hence no ${ }^{13} \mathrm{C} N M R$ spectrum neither microanalytical data could be obtained.
However, it was used in-situ to prepare the cyclometalated platinum complexes 2-5.

General procedure for $\left(C^{\wedge} \mathrm{N}\right) \mathrm{Pt}\left(\eta-\mathrm{S}^{\wedge} \mathrm{S}\right)$ complexes.

Cyclometalated platinum dimer $\left[\left(\mathrm{C}^{\wedge} \mathrm{N}\right) \mathrm{Pt}(\mu-\mathrm{Cl})\right]_{2}(0.06 \mathrm{mmol})$ and silver triflate $(32 \mathrm{mg}, 0.13 \mathrm{mmol}$ ) were introduced into a Schlenk tube containing $10 \mathrm{~mL}$ of acetonitrile. The reaction mixture was stirred in the dark, at room temperature for two hours, then it was filtered on a plug of celite, and concentrated to $2 \mathrm{~mL}$. To the resulting solution presumably $\left[\left(\mathrm{C}^{\wedge} \mathrm{N}\right) \mathrm{Pt}(\mathrm{MeCN})_{2}\right][\mathrm{OTf}]$ was added [Na] $\left[\mathrm{Cp}{ }^{*} \mathrm{Ru}\left(\eta-\mathrm{C}_{6} \mathrm{H}_{4} \mathrm{~S}_{2}\right)\right](\mathrm{Na}-1)$ in $4 \mathrm{~mL}$ of $\mathrm{CH}_{3} \mathrm{CN}$ to give immediately a precipitate, which was filtered off and washed with $2 \mathrm{~mL}$ of acetonitrile followed by $4 \mathrm{~mL}$ of diethylether. This solid was then dissolved in $10 \mathrm{~mL}$ of dichloromethane and filtered through a plug of celite. The filtrate was evaporated and the microcrystalline powder was dried under vacuum providing the neutral cyclometalated $\left(C^{\wedge} N\right) P t\left(\eta-S^{\wedge} S\right)$ compounds (2-5).

\section{Synthesis of [(ppy)Pt(Cp* Ru(n- $\left.\left.\mathrm{C}_{6} \mathrm{H}_{4} \mathrm{~S}_{2}\right)\right]$ (2)}

Starting with $46 \mathrm{mg}$ of $[(\mathrm{ppy}) \mathrm{Pt}(\mu-\mathrm{Cl})]_{2}$, compound $\mathbf{2}$ was isolated as a yellow microcrystalline solid. Yield (56 mg, 51\%). ${ }^{1} \mathrm{H}$ NMR $\left(400 \mathrm{MHz}, \mathrm{CD}_{2} \mathrm{Cl}_{2}\right) \delta: 9.03$ (d with satellites, $J=5.1 \mathrm{~Hz}, J_{\mathrm{H}-}$ $\left.{ }_{P t}=34.1 \mathrm{~Hz}, 1 \mathrm{H}, \mathrm{ppy}\right), 7.83$ (td, J=10.8, $\left.2 \mathrm{~Hz}, 1 \mathrm{H}, \mathrm{ppy}\right), 7.76(\mathrm{~m}$, $2 \mathrm{H}, \mathrm{ppy}), 7.58$ (dd, J=8.4, 3.6 Hz, 1H, ppy), 7.08 (m, 3H,ppy), $5.73(\mathrm{~m}, 2 \mathrm{H}, \mathrm{H}$-arene), 5.05 (m, 2H, $\mathrm{H} \pi$-arene), $1.76(\mathrm{~s}, 15 \mathrm{H}$, Cp*). ${ }^{13} \mathrm{C}$ NMR $\left(100 \mathrm{MHz}, \mathrm{CD}_{2} \mathrm{Cl}_{2}\right) \delta: 150.2,144.8,137.4,134.1$, 130.7, 124.1, 122.9, 122.6, 119.3, 92.2, 88.6, 87.3, 82.3, 81.8, 9.4.IR $\left(\right.$ ATR, $\left.\mathrm{cm}^{-1}\right): 3039,1602,1581,1476,1404,1376,1347$, 1266, 1204, 1160, 1080, 1029, 754, 731, 661, 505, 447, 355. Anal. Calcd for $\mathrm{C}_{27} \mathrm{H}_{27} \mathrm{NS}_{2}$ RuPt C, 44.68; $\mathrm{H}, 3.75$. Found: C, 44.86; H, 4.10 .

\section{Synthesis of [(F2ppy)Pt(Cp*Ru(n-C $\left.\left.\mathrm{C}_{6} \mathrm{H}_{4} \mathrm{~S}_{2}\right)\right]$ (3)}

Using $52 \mathrm{mg}$ of $[(\mathrm{F} 2 \mathrm{ppy}) \mathrm{Pt}(\mu-\mathrm{Cl})]_{2}$ compound $\mathbf{3}$ was obtained as a light yellow solid. Yield (17 mg, 18\%). ${ }^{1} \mathrm{H}$ NMR (400 MHz, $\mathrm{CD}_{2} \mathrm{Cl}_{2}$ ) $\delta: 9.08$ (d with satellites, $J=5.2 \mathrm{~Hz}, J_{H-P t}=33.6 \mathrm{~Hz}, 1 \mathrm{H}$, F2ppy), 8.12 (d, J=7.2 Hz, 1H, F2ppy), 7.86 (t, J=7.8 Hz, 1H, F2ppy), 7.35 (dd, J=8.8, $2.4 \mathrm{~Hz}, J_{H-P t}=53.6 \mathrm{~Hz}, 1 \mathrm{H}, \mathrm{F} 2 \mathrm{ppy}$ ), 7.08 (t, J=6.4 Hz, 1H, F2ppy), 6.56 (td, $J_{H-F}=11.0 \mathrm{~Hz}, J_{H-H}=2.4 \mathrm{~Hz}, 1 \mathrm{H}$, F2ppy), $5.73(\mathrm{~m}, 2 \mathrm{H}, \pi$-arene), 5.07 ( $\mathrm{m}, 2 \mathrm{H}, \pi$-arene), 1.75 (s, $\left.15 \mathrm{H}, \mathrm{Cp}^{*}\right) \cdot{ }^{19} \mathrm{~F}$ NMR $\left(375 \mathrm{MHz}, \mathrm{CD}_{2} \mathrm{Cl}_{2}\right) \delta:-109.3\left(\mathrm{~d}, J_{F-F}=7.5 \mathrm{~Hz}\right.$, $\left.J_{F-P t}=60,2 \mathrm{~Hz}\right),-111.5\left(\mathrm{~d}, J_{F-F}=7.5 \mathrm{~Hz}, J_{F-P t}=37.7 \mathrm{~Hz}\right) .{ }^{13} \mathrm{C}$ NMR

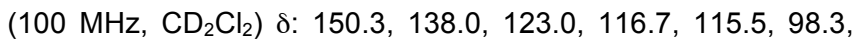
92.3, 88.5, 87.3, 82.4, 82.0, 9.39. IR (ATR, $\mathrm{cm}^{-1}$ ): 2960, 2917, $2849,1599,1567,1475,1399,1382,1259,1243,1165,10082$, 1010, 795, 755, 704, 661, 506, 378, 313. Anal. Calcd for $\mathrm{C}_{27} \mathrm{H}_{25} \mathrm{~F}_{2} \mathrm{NS}_{2}$ RuPt.2( $\left.\mathrm{C}_{4} \mathrm{H}_{10} \mathrm{O}\right) .0 .5 \mathrm{H}_{2} \mathrm{O} \mathrm{C}, 44.77 ; \mathrm{H}, 4.87$. Found: $\mathrm{C}$, 44.61; H, 4.91.

\section{Synthesis of [(bzq)Pt(Cp* Ru(n- $\left.\left.\mathrm{C}_{6} \mathrm{H}_{4} \mathrm{~S}_{2}\right)\right]$ (4)}

Using $49 \mathrm{mg}$ of $[(\mathrm{bzq}) \mathrm{Pt}(\mu-\mathrm{Cl})]_{2}$. Compound $\mathbf{4}$ was obtained as a brown-yellow solid. Yield (49 mg, 55\%). ${ }^{1} \mathrm{H}$ NMR (400 MHz, $\mathrm{CD}_{2} \mathrm{Cl}_{2}$ ) : 9.27 (d with satellites, $J=4.9 \mathrm{~Hz}, J_{H-P t}=34.2 \mathrm{~Hz}, 1 \mathrm{H}$, bzq), 8.33 (dd, J=8.0, $1.2 \mathrm{~Hz}, 1 \mathrm{H}$, bzq), 7.95 (dd, J=6.9, $0.8 \mathrm{~Hz}$, $\left.J_{H-P t}=41.8 \mathrm{~Hz}, 1 \mathrm{H}, \mathrm{bzq}\right), 7.78(\mathrm{~d}, J=8.8 \mathrm{~Hz}, 1 \mathrm{H}, \mathrm{bzq}), 7.59(\mathrm{t}$, $J=9.0 \mathrm{~Hz}, 2 \mathrm{H}, \mathrm{bzq}), 7.51$ (t, $J=7.6 \mathrm{~Hz}, 1 \mathrm{H}, \mathrm{bzq}), 7.43$ (t, $J=6.8$, $2.4 \mathrm{~Hz}, 1 \mathrm{H}, \mathrm{bzq}), 5.79(\mathrm{~m}, 2 \mathrm{H}, \pi$-arene), 5.08 (m, 2H, $\pi$-arene), 1.77(s, $\left.15 \mathrm{H}, \mathrm{Cp}^{*}\right) .{ }^{13} \mathrm{C}$ NMR $\left(100 \mathrm{MHz}, \mathrm{CD}_{2} \mathrm{Cl}_{2}\right) \delta: 157.4,153.6$, $148.4,136.4,134.5,130.8,130.3,129.8,123.5,122.3,122.1$, 
120.6, 92.2, 88.6, 87.3, 82.3, 81.9, 9.4. IR (ATR, $\left.\mathrm{cm}^{-1}\right): 3032$, 2917, 2851, 1616, 1562, 1444, 1404, 1375, 1327, 1203, 1080, $1030,832,760,715,661,504,443,355$. Anal. Calcd for $\mathrm{C}_{29} \mathrm{H}_{27} \mathrm{NS}_{2}$ RuPt.0.5 $\mathrm{H}_{2}$ O. C, 45.90; $\mathrm{H}, 3.72$ Found: C, 46.02; $\mathrm{H}$, 4.10.

\section{Synthesis of $\left[(\mathrm{dbzq}) \mathrm{Pt}\left(\mathrm{Cp} \mathrm{Ru}^{*}\left(\boldsymbol{\eta}-\mathrm{C}_{6} \mathrm{H}_{4} \mathrm{~S}_{2}\right)\right](5)\right.$}

Starting from $50 \mathrm{mg}$ of $[(\mathrm{dbzq}) \mathrm{Pt}(\mu-\mathrm{Cl})]_{2}$. Compound 5 was obtained as a brownish-yellow solid. Yield (40 mg, 47\%). ${ }^{1} \mathrm{H}$ NMR (400 MHz, $\mathrm{CD}_{2} \mathrm{Cl}_{2}$ ) $\delta: 9.31$ (d with satellites, $J=5.4 \mathrm{~Hz}, J_{H-}$ $P_{t}=34.2 \mathrm{~Hz}, 1 \mathrm{H}, \mathrm{dbzq}$ ), 8.99 (dd, $\left.\mathrm{J}=8.4,1.2 \mathrm{~Hz}, 1 \mathrm{H}, \mathrm{dbzq}\right), 8.67$ (dd, $J=7.8,1.6 \mathrm{~Hz}, 1 \mathrm{H}, \mathrm{dbzq}$ ), 8.60 (dd, $J=7.5,1.6 \mathrm{~Hz}, 1 \mathrm{H}, \mathrm{dbzq}$ ), 8.24 (d, J=7.8, $1 \mathrm{H}, \mathrm{dbzq}), 7.98$ (dd, J=7.5Hz, $0.8 \mathrm{~Hz} ; J_{H-P t}=34.2$ $\mathrm{Hz}, 1 \mathrm{H}, \mathrm{dbzq}), 7.78-7.66$ (m, 2H, dbzq), 7.55 (t, J=7.6 Hz, 1H, $\mathrm{dbzq}), 7.50-7.46(\mathrm{~m}, 1 \mathrm{H}, \mathrm{dbzq}), 5.80-5.77(\mathrm{~m}, 2 \mathrm{H}, \pi$-arene $)$, 5.10-5.08 (m, 2H, $\pi$-arene), $1.77\left(\mathrm{~s}, 15 \mathrm{H}, \mathrm{Cp}^{*}\right) .{ }^{13} \mathrm{C}$ NMR $(100$ $\left.\mathrm{MHz}, \mathrm{CD}_{2} \mathrm{Cl}_{2}\right) \delta: 131.7,130.8,128.7,127.4,124.2,123.9,92.2$, 91.9, 9.4. IR (ATR, $\left.\mathrm{cm}^{-1}\right)$ : 2951, 2906, 1569, 1430, 1379, 1261, $1082,1051,795,756,712,661,630,505,448,359,339$. X-ray structure confirms the formation of the desired complex.

\section{Synthesis of [(bpy)Pt(Cp*Ru(n- $\left.\left.\mathrm{C}_{6} \mathrm{H}_{4} \mathrm{~S}_{2}\right)\right][\mathrm{OTf}]$ (6)}

A solution of [(bpy)Pt $\left.\left(\mathrm{C}_{6} \mathrm{H}_{4} \mathrm{~S}_{2}\right)\right](40 \mathrm{mg}, 0,08 \mathrm{mmol}$.) in $10 \mathrm{~mL}$ of $\mathrm{CH}_{2} \mathrm{Cl}_{2}$ was transferred under argon by canula to a solution of

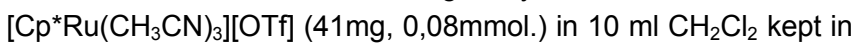
a Schlenk tube under argon. The reaction was left to proceed for $18 \mathrm{~h}$, then solvent was concentrated under vacuum, subsequent addition of $\mathrm{Et}_{2} \mathrm{O}$ provided a red purple precipitate, that was filtered and dried under vacuum. Yield $(67 \mathrm{mg}, 93 \%)$.

${ }^{1} \mathrm{H}$ NMR $\left(400 \mathrm{MHz}, \mathrm{CD}_{3} \mathrm{CN}\right.$ ) $\delta: 8.97$ (d with satellites, $J=5.0 \mathrm{~Hz}$, $\left.J_{H-P t}=34.8 \mathrm{~Hz}, 2 \mathrm{H}, \mathrm{bpy}\right), 8.35$ (dd, J=8,0, $2 \mathrm{~Hz}, 2 \mathrm{H}, \mathrm{bpy}$ ), 8.29 (dt, $J=7.8,1.5 \mathrm{~Hz}, 2 \mathrm{H}, \mathrm{bpy}), 7.68$ (dt, J=6.6, $1.6 \mathrm{~Hz}, 2 \mathrm{H}, \mathrm{bpy}), 5,81-$

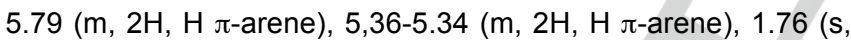
$\left.15 \mathrm{H}, \mathrm{Cp}^{*}\right) .{ }^{13} \mathrm{C}$ NMR $\left(100 \mathrm{MHz}, \mathrm{CD}_{2} \mathrm{Cl}_{2}\right) \delta: 156.9,149.6,141.0$, 134.1, 129.5, 125.4, 115.2, 94.1, 87.1, 84.4, 9.4. ${ }^{19} \mathrm{~F}$ NMR $(375$ $\left.\mathrm{MHz}, \mathrm{CD}_{3} \mathrm{CN}\right) \delta:-78,8 . \mathrm{IR}\left(\mathrm{ATR}, \mathrm{cm}^{-1}\right): 3080,2958,2919,1724$, $1604,1496,1448,1403,1382,1256,1222,1151,1090,1029$, 848, 752, 634, 506, 450, 375. Anal. Calcd for $\mathrm{C}_{27} \mathrm{H}_{27} \mathrm{~N}_{2} \mathrm{~S}_{3} \mathrm{~F}_{3} \mathrm{O}_{3}$ RuPt.2H $\mathrm{H}_{2} \mathrm{O}$. C, 35.52; H, 3.42. Found: C, 35.35; $\mathrm{H}, 3.31$.

\section{X-ray Structural determination of compounds $2-3,5$ and 6}

Suitable crystals for $\mathrm{X}$-ray diffraction study were grown through slow evaporation of diethyl ether into a saturated dichloromethane (2, 3 and 5 ) or acetone (6) solution of the desired compound. A single crystal was selected, mounted and transferred into a cold nitrogen gas stream. Intensity data was collected with Bruker Kappa-APEX2 systems using Cu-Ka micro-source (2) or Mo-Ka fine-focus sealed tube (3, 5 and 6 ) radiation. Data collection was carried out with the Bruker APEX2 suite of programs. Unit-cell parameters determination, integration and data reduction were performed with SAINT. SADABS was used for scaling and multi-scan absorption corrections. The structures were solved using $\operatorname{SIR} 92^{[56]}(2,3$ and 5) or SHELXS-86 $6^{[57]}(6)$ and refined by full-matrix least-squares methods using SHELXL-2013. ${ }^{[57]}$ or CRYSTALS. ${ }^{[58]}$ All nonhydrogen atoms were refined anisotropically. Hydrogen atoms were placed at calculated positions and refined with a riding model. Crystals of 2, 3 and $\mathbf{5}$ contain a combination of the two enantiomers disordered over the same positions. Refinement of the corresponding site occupancy factors led to ratios of 50:50 (2 and 5) and 67:33 (3). Crystallographic data for these structures was deposited at the Cambridge Crystallographic Data Centre with numbers 996068 (2), 996069 (3), 1469845 (5) and 1469846 (6). Data can be obtained free of charge via www.ccdc.cam.ac.uk.

\section{Photochemistry}

All solvents used for photophysical determinations were of spectrophotometric grade (VWR) and were used without further purification. The absorption spectra were recorded at room temperature (rt) on a Perkin-Elmer Lambda 950 UV/Vis/NIR spectrophotometer using $1 \mathrm{~cm}$ optical path length Suprasil Quartz (QS) Hellma cuvettes. Molar extinction coefficients $(\varepsilon)$ were calculated by applying the Lambert-Beer law to low absorbance spectra $(A<1)$ recorded at successive dilutions. Steady-state photoluminescence spectra were measured in right angle mode using an Edinburgh FLS920 fluorimeter, equipped with a Xenon arc lamp and a Hamamatsu R928P Peltier-cooled photomultiplier tube. The concentration of sample solutions was adjusted to obtain absorption values $A<0.1$ at the excitation wavelength; when needed, the solutions were de-aerated, by bubbling Argon for at least 20 minutes in custom made gas-tight cuvettes. Photoluminescence spectra at $77 \mathrm{~K}$ were recorded by employing quartz capillary tubes immersed in liquid nitrogen, and hosted within a homemade quartz cold-finger Dewar. All emission spectra were corrected for the wavelength dependent phototube response between 200 and $900 \mathrm{~nm}$ using a calibration curve provided by the manufacturer. The absorption and emission band maxima are obtained with uncertainty of 1 $\mathrm{nm}$. Luminescence quantum efficiencies $(\phi)$ were evaluated with a $20 \%$ uncertainty by comparing the wavelength integrated intensities of corrected spectra with reference to $\left[\mathrm{Ru}(\mathrm{bpy})_{3}\right] \mathrm{Cl}_{2}\left(\phi_{\mathrm{r}}\right.$ $=0.028$ in air-equilibrated water) ${ }^{[59]}$ The luminescence lifetimes were obtained using a Jobin-Yvon IBH 5000F TCSPC apparatus equipped with a TBX Picosecond Photon Detection Module and NanoLED/SpectraLED pulsed excitation sources. Analysis of luminescence decay profiles against time was accomplished using the Decay Analysis Software DAS v6.5 (HORIBA Jobin Yvon), obtaining lifetime values with an estimated uncertainty of $10 \%$.

\section{Acknowledgements}

We would like to thank the UMPC, CNRS and French ANR (Project OPTOELECTR-OM ANR-11-BS07-001-01) for financial support. Financial support from the Italian CNR (project Photonics for Health, Energy and Environment PHEEL, Bilateral Cooperation Projects CNR/CONICET and CNR/CNRS-L), and the Italian MIUR (Flagship Project Nanomax N-CHEM) are also acknowledged. 
[1] J. A. G. Williams, in Photochemistry and Photophysics of Coordination Compounds II, Vol. 281 (Eds.: V. Balzani, S. Campagna), 2007, pp. 205. [2] J. A. G. Williams, S. Develay, D. L. Rochester, L. Murphy, Coord. Chem. Rev. 2008, 252, 2596

[3] J. A. G. Williams, Chem. Soc. Rev. 2009, 38, 1783

[4] K. M.-C. Wong, V. W.-W. Yam, Coord. Chem. Rev. 2007, 251, 2477

[5] K. M.-C. Wong, V. W.-W. Yam, Acc. Chem. Res 2011, 44, 424

[6] Y. Chi, P.-T. Chou, Chem. Soc. Rev. 2010, 39, 638.

[7] S. W. Thomas, S. Yagi, T. M. Swager, J. Mat. Chem. 2005, 15, 2829.

[8] S. W. Thomas, III, K. Venkatesan, P. Muller, T. M. Swager, J. Am. Chem. Soc. 2006, 128, 16641.

[9] J. C.-H. Chan, W. H. Lam, H.-L. Wong, N. Zhu, W.-T. Wong, V. W.-W. Yam, J. Am. Chem. Soc. 2011, 133, 12690.

[10] Y.-L. Rao, S. Wang, Organometallics 2011, 30, 4453

[11] X. Mou, Y. Wu, S. Liu, M. Shi, X. Liu, C. Wang, S. Sun, Q. Zhao, X. Zhou, W. Huang, J. Mat. Chem. 2011, 21, 13951.

[12] A. Diez, J. Fornies, A. Garcia, E. Lalinde, M. T. Moreno, Inorg. Chem. 2005, 44, 2443.

[13] S. Culham, P.-H. Lanoe, V. L. Whittle, M. C. Durrant, J. A. G. Williams, V. N. Kozhevnikov, Inorg. Chem. 2013, 52, 10992.

[14] V. Sicilia, J. Fornies, J. Ma Casas, A. Martin, J. A. Lopez, C. Larraz, P. Borja, C. Ovejero, D. Tordera, H. Bolink, Inorg. Chem. 2012, 51, 3427.

[15] L. Chassot, E. Muller, A. Vonzelewsky, Inorg. Chem. 1984, 23, 4249.

[16] M. Maestri, D. Sandrini, V. Balzani, L. Chassot, P. Jolliet, A. Vonzelewsky, Chem. Phys. Lett. 1985, 122, 375.

[17] L. Chassot, A. Vonzelewsky, D. Sandrini, M. Maestri, V. Balzani, J. Am Chem. Soc. 1986, 108, 6084

[18] L. Chassot, A. Vonzelewsky, Inorg. Chem. 1987, 26, 2814.

[19] J. Kalinowski, V. Fattori, M. Cocchi, J. A. G. Williams, Coord. Chem. Rev. 2011, 255, 2401.

[20] B. Yin, F. Niemeyer, J. A. G. Williams, J. Jiang, A. Boucekkine, L. Toupet, H. Le Bozec, V. Guerchais, Inorg. Chem. 2006, 45, 8584

[21] A. Bossi, A. F. Rausch, M. J. Leitl, R. Czerwieniec, M. T. Whited, P. I. Djurovich, H. Yersin, M. E. Thompson, Inorg. Chem. 2013, 52, 12403.

[22] F. Niedermair, O. Kwon, K. Zojer, S. Kappaun, G. Trimmel, K. Mereiter, C. Slugovc, Dalton Trans. 2008, 4006.

[23] F. Niedermair, R. Trattnig, K. Mereiter, M. Schmuck, S. Sax, E. J. W. List, C. Slugovc, Montash. F. Chem. 2010, 141, 847.

[24] Q. X. Liu, H. B. Song, F. B. Xu, Q. S. Li, X. S. Zeng, X. B. Leng, Z. Z. Zhang, Polyhedron 2003, 22, 1515.

[25] Y. Unger, A. Zeller, S. Ahrens, T. Strassner, Chem. Comm. 2008, 3263.

[26] H. Uesugi, T. Tsukuda, K. Takao, T. Tsubomura, Dalton Trans. 2013 42, 7396 .

[27] J. Moussa, T. Cheminel, G. R. Freeman, L.-M. Chamoreau, J. A. G. Williams, H. Amouri, Dalton Trans. 2014, 43, 8162.

[28] H. R. Shahsavari, M. Fereidoonnezhad, M. Niazi, S. T. Mosavi, S. Habib Kazemi, R. Kia, S. Shirkhan, S. Abdollahi Aghdam, P. R. Raithby, Dalton Trans. 2017, 46, 2013.

[29] F. Julia, P. G. Jones, P. Gonzalez-Herrero, Inorg. Chem. 2012, 51, 5037.

[30] H. Sesolis, J. Moussa, G. Gontard, A. Jutand, M. P. Gullo, A. Barbieri, H. Amouri, Dalton Trans. 2015, 44, 2973.

[31] H. Amouri, Synlett 2011, 1357.
[32] H. Amouri, J. Vaissermann, Y. Besace, K. P. C. Vollhardt, G. E. Ball, Organometallics 1993, 12, 605

[33] H. Amouri, R. Thouvenot, M. Gruselle, B. Malezieux, J. Vaissermann Organometallics 2001, 20, 1904.

[34] D. Vichard, M. Gruselle, H. Amouri, G. Jaouen, J. Chem. Soc. Chem. Comm. 1991, 46.

[35] H. Amouri, M. Gruselle, P. A. Jackson, G. Jaouen, J. Vaissermann, Organometallics 1990, 9, 2871

[36] H. Amouri, J. Moussa, A. K. Renfrew, P. J. Dyson, M. N. Rager, L.-M. Chamoreau, Angew. Chem. Int. Ed. 2010, 49, 7530.

[37] J. Moussa, D. A. Lev, K. Boubekeur, M. N. Rager, H. Amouri, Angew. Chem. Int. Ed. 2006, 45, 3854.

[38] J. Moussa, M. N. Rager, K. Boubekeur, H. Amouri, Eur. J. Inorg. Chem. 2007, 2648.

[39] J. Moussa, H. Amouri, Angew. Chem. Int. Ed. 2008, 47, 1372.

[40] J. Moussa, M. N. Rager, L. M. Chamoreau, L. Ricard, H. Amouri, Organometallics 2009, 28, 397.

[41] A. Damas, B. Ventura, M. R. Axet, A. Degli Esposti, L.-M. Chamoreau, A. Barbieri, H. Amouri, Inorg. Chem. 2010, 49, 10762

[42] A. Damas, B. Ventura, J. Moussa, A. Degli Esposti, L.-M. Chamoreau, A. Barbieri, H. Amouri, Inorg. Chem. 2012, 51, 1739.

[43] A. Damas, M. P. Gullo, M. N. Rager, A. Jutand, A. Barbieri, H. Amouri, Chem. Comm. 2013, 49, 3796.

[44] J. Moussa, K. M.-C. Wong, L.-M. Chamoreau, H. Amouri, V. W.-W. Yam, Dalton Trans. 2007, 3526.

[45] J. Moussa, K. M.-C. Wong, X. F. Le Goff, M. N. Rager, C. K.-M. Chan V. W.-W. Yam, H. Amouri, Organometallics 2013, 32, 4985.

[46] J. Moussa, L.-M. Chamoreau, A. D. Esposti, M. P. Gullo, A. Barbieri, H. Amouri, Inorg. Chem. 2014, 53, 6624

[47] W. B. Connick, H. B. Gray, J. Am. Chem. Soc. 1997, 119, 11620.

[48] M. A. Mansour, R. J. Lachicotte, H. J. Gysling, R. Eisenberg, Inorg. Chem. 1998, 37, 4625

[49] Y. Suga, M. Nakano, H. Tamura, G. E. Matsubayashi, Bull. Chem. Soc Jpn. 2004, 77, 1877.

[50] A. Damas, L. M. Chamoreau, A. L. Cooksy, A. Jutand, H. Amouri, Inorg Chem. 2013, 52, 1409 .

[51] M. G. Colombo, T. C. Brunold, T. Riedener, H. U. Gudel, M. Fortsch, H B. Burgi, Inorg. Chem. 1994, 33, 545.

[52] W. Paw, S. D. Cummings, M. A. Mansour, W. B. Connick, D. K. Geiger R. Eisenberg, Coord. Chem. Rev. 1998, 171, 125.

[53] R. Englman, J. Jortner, Mol. Phys. 1970, 18, 145.

[54] J. V. Caspar, E. M. Kober, B. P. Sullivan, T. J. Meyer, J. Am. Chem. Soc. 1982, 104, 630.

[55] J. P. Sauvage, J. P. Collin, J. C. Chambron, S. Guillerez, C. Coudret, V. Balzani, F. Barigelletti, L. Decola, L. Flamigni, Chem. Rev. 1994, 94, 993.

[56] A. Altomare, G. Cascarano, C. Giacovazzo, A. Guagliardi, J. Appl. Cryst. 1993, 26, 343.

[57] G. M. Sheldrick, Acta. Cryst. Sec. A 2008, 64, 112

[58] P. W. Betteridge, J. R. Carruthers, R. I. Cooper, K. Prout, D. J. Watkin, J. Appl. Cryst. 2003, 36, 1487

[59] M. Montalti, A. Credi, L. Prodi, M. T. Gandolfi, in Handbook of Photochemistry, 3rd ed., CRC Press, Boca Raton, FL (USA), 2006, pp. 561. 


\section{Entry for the Table of Contents}

\section{Full Paper}

A convenient synthetic procedure is described for the preparation of cyclometalated platinum(II) complexes $\left[\left(C^{\wedge} N\right) P t\left(\eta-S^{\wedge} S\right)\right](2-5)$ from $\pi$-bonded benzenedithiolate $\left(\eta-S^{\wedge} S=\left[C p^{*} R u\left(\eta-C_{6} H_{4} S_{2}\right)\right]^{-}(1)\right.$. The molecular structures of 2,3 and $\mathbf{5}$ were ascertained by $\mathrm{X}$-ray diffractions study. Their electrochemical and photophysical properties are reported.
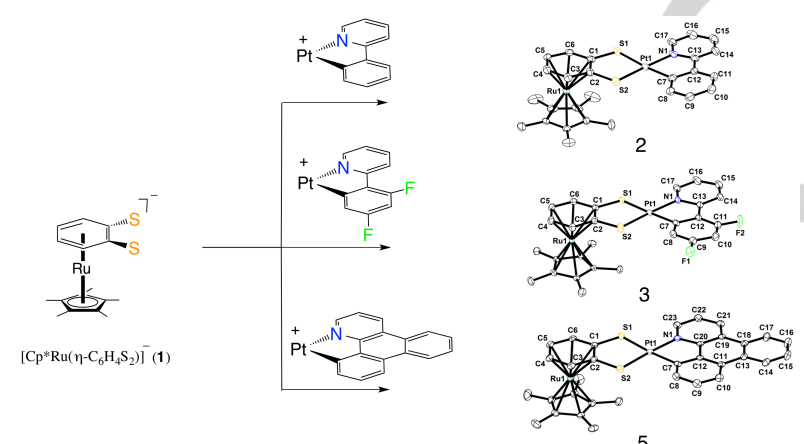

H. Sesolis, G. Gontard, A. Jutand*, M. P. Gullo, E. Bandini, A. Barbieri" and $\mathrm{H}$. Amouri*

Page No. - Page No.

Convenient Approach to Luminescent Cyclometalated Platinum(II) Complexes with Organometallic $\pi$-bonded Benzenedithiolate 